\title{
Detailed rock failure susceptibility mapping in steep rocky coasts by means of non-contact geostructural surveys: the case study of the Tigullio Gulf (Eastern Liguria, Northern Italy)
}

\author{
P. De Vita ${ }^{1}$, A. Cevasco ${ }^{2}$, and C. Cavallo ${ }^{3}$ \\ ${ }^{1}$ Università di Napoli “Federico II", Dipartimento di Scienze della Terra, Largo San Marcellino, 10, 80132 Napoli, Italy \\ ${ }^{2}$ Università di Genova, Dipartimento per lo Studio del Territorio e delle sue Risorse, 16132 Genova, Italy \\ ${ }^{3}$ Regione Liguria, Settore Ecosistema Costiero, Via D’Annunzio, 111, 16121 Genova, Italy
}

Correspondence to: P. De Vita (padevita@unina.it)

Received: 21 April 2011 - Accepted: 19 February 2012 - Published: 10 April 2012

\begin{abstract}
In this study, an engineering geological analysis for the assessment of the rock failure susceptibility of a high, steep, rocky coast was developed by means of non-contact geostructural surveys. The methodology was applied to a 6-km coastal cliff located in the Gulf of Tigullio (Northern Tyrrhenian Sea) between Rapallo and Chiavari.

The method is based on the geostructural characterisation of outcropping rock masses through meso- and macroscale stereoscopic analyses of digital photos that were taken continuously from a known distance from the coastline. The results of the method were verified through direct surveys of accessible sample areas. The rock failure susceptibility of the coastal sector was assessed by analysing the fundamental rock slope mechanisms of instability and the results were implemented into a Geographic Information System (GIS).

The proposed method is useful for rock failure susceptibility assessments in high, steep, rocky coastal areas, where accessibility is limited due to cliffs or steep slopes. Moreover, the method can be applied to private properties or any other area where a complete and systematic analysis of rock mass structural features cannot be achieved.

Compared to direct surveys and to other non-contact methods based on digital terrestrial photogrammetry, the proposed procedure provided good quality data of the structural features of the rock mass at a low cost. Therefore, the method could be applied to similar coastal areas with a high risk of rock failure occurrence.
\end{abstract}

\section{Introduction}

The management of coastal areas is a crucial and relevant issue that requires the adoption of comprehensive solutions (Clark, 1992). To improve the management of coastal areas, the contracting parties of the Convention for the Protection of Marine and Coastal Regions (a.k.a. the Barcelona Convention) adopted new protocols for the integrated management of the coastal areas of the Mediterranean region. The agreement was opened for signatures in Madrid in January 2008, and was signed by Italy. In accordance with the agreement, the Ligurian regional government issued the Plan for the Protection of Marine and Coastal Environments. The plan protects the region by implementing soil conservation rules and providing further objectives, such as the management of landslide risk for public safety and the protection of coastal areas with high natural value.

Approximately $40 \%$ of Ligurian coasts (northwestern Italy) have a high and steep morphology, and the eastern region of Liguria is dominated by steep cliffs. In general, the Ligurian coast consists of rocky, steep slopes that rapidly decline toward the sea from watersheds running parallel to the coastline. Moreover, at the base of the slope, a cliff is often observed. Along eastern Ligurian coasts, urban areas alternate with natural regions; the former are generally located along narrow alluvial and littoral plains and the latter are found in steep rocky sectors. Several studies (De Stefanis et al., 1985; Terranova, 1984; Cevasco et al., 2000; Federici et al., 2001; Cevasco, 2007) have focused on the stability of the rock masses on the eastern Ligurian coast. In this region, active coastal slope dynamics interfere with 




Fig. 1. Location map of the study area.

man-made structures (settlements, residential areas, routes and railways), human activities (agricultural practices on traditional "terraces", tourist activities along the coast) and sedimentary dynamics.

The aim of this study was to develop a cost-effective and reliable methodology for the assessment of landslide susceptibility (Radbruch, 1970; Dobrovolny, 1971; Brabb et al., 1972) for land-use planning in extensive, steep, rocky coast sectors. The proposed methodology can be conceived as an advanced method (Fell et al., 2008), owing to the detailed scale of the analysis. The application of the proposed method is a preliminary and necessary step in identifying areas that are at risk for rock-slope instability, as required by the abovementioned regulations even with a relative approach (Canuti et al., 1998).

The assessment of landslide susceptibility along steep coasts is a commonly studied subject due to the economic value of coastal areas and the high risk of landslides and marine erosion (Iadanza et al., 2009). A number of studies on large coastal landslides involving soils (Cotecchia, 1997, 2006; Fiorillo, 2003) and rock masses (Angeli et al., 1992; Hutchinson and Bromhead, 2002; Ferrero et al., 2011) have been conducted. Alternatively, others studies have focused on entire costal sectors. For instance, sea-cliff erosion in rocky coasts has been evaluated (Andriani and Walsh, 2007; Jongens et al., 2007), and the landslide risk of coastal settlements has been determined. Various methods for landslide susceptibility mapping of extended coastal sectors have been proposed, including the application of high-resolution topographic surveys (Schulz, 2007), parametric methods (Budetta et al., 2008) and a rock slope distributed landslide susceptibility model (Günther and Thiel, 2009).
In this study, a 6-km, partially urbanised coastal area consisting of steep rocky slopes and cliffs was selected as the test area. The assessment of susceptibility to failure of rocky slopes was not extended to the determination of landslide hazards due to the difficulty in gathering sufficient data on the historical records of rock failures and the lack of information on the factors that affect their occurrence (i.e., rainfall, waves at the toe of the cliff and earthquakes).

According to Fell et al. (2008), landslide susceptibility mapping involves classifying and assessing the spatial distribution of existing and potential landslides. Due to the characteristics of the rock masses in the study area, the fundamental potential failures in rock slopes include plane sliding, wedge sliding and toppling (Hoek and Londe, 1974). Hence, rock failure susceptibility assessment requires a careful understanding of the structural features of the rock mass.

\section{Study area}

The study area is located along the western Ligurian coast (Northern Italy) between the towns of Rapallo and Chiavari, $30 \mathrm{~km}$ east of Genoa. The study area is $5.7 \mathrm{~km}$ long and approximately rectilinear with a $\mathrm{N} 116^{\circ}$ trend (Fig. 1). Many coastal sectors in the study region are characterised by rocky slopes with a general SW exposure that degrade steeply toward the sea from the principal watershed, which parallels the coastline. Due to this structural feature, the hydrographic pattern is directly oriented seaward and generally characterised by short and low-order hydrographic channels with a steep profile and high erosive action. Consequently, catchments are very small, and the largest stream, Fosso Semorile, has an area of approximately $3.8 \mathrm{~km}^{2}$. 




Fig. 2. Geological sketch of the study area (Elter et al., 2005; modified): (1) embankments; (2) beach deposits; (3) alluvial deposits; (4) eluvium/colluvium; (5) landslides in detrital deposits (dormant); (6) landslides in detrital deposits (active); (7) Mt. Antola Flysch; (8) Manganesiferi Shales; (9) Palombini Shales; (10) faults; (11) normal faults; (12) reverse faults; (13) transcurrent faults; (14) thrusts; (15) attitude of the bedding planes; (16) survey stations; (17) test areas.

Although the coastline possesses a linear trend at a large scale, a more detailed observation reveals a series of small bays and headlands. Due to their small extensions, the coastline rarely contains pocket beaches, even though a relatively extensive beach exists in the town of Zoagli, which is located at the mouth of the Fosso Semorile stream.

In the coastal sector between Rapallo and Chiavari, vertical cliffs and rocky slopes with a slope angle greater than $35^{\circ}$ are 5 to $150 \mathrm{~m}$ tall, forming a quasi-continuous outcropping of rock masses that extend for approximately $0.37 \mathrm{~km}^{2}$ (if considering the surface corresponding to the sum of the slope faces). The rock mass is interrupted only by small beaches corresponding to the outlet of the aforementioned catchments.

From a geological point of view, the area (Fig. 2) is entirely characterised by the outcropping of flysch formations ascribed to the Antola Unit, which is one of the most important tectonic units in the northern Apennines. The Antola Unit includes the Montoggio claystones, attributed to the Campanian (Marroni et al., 1992), the Mt. Antola limestones, Upper Campanian-Paleocene (Marroni et al., 1992) and the Pagliaro claystones (Paleocene or Lower Eocene). In particular, the Mt. Antola limestones (also called Mt. Antola Flysch) are located in the study area.

The Mt. Antola limestones consist mainly of turbiditic layers of marly limestones and marls, as well as calcarenites and variable layers of clayey marls and mudstones (Elter et al., 2005), deposited in an abyssal plain above the CCD. Many studies have been conducted to define the metamorphic conditions of the Mt. Antola limestones. An analysis of the crystallinity of the illite in the rock mass revealed that the metamorphic processes did not exceed the diagenesis field (Venturelli and Frey, 1977; Cortesogno and Haccard, 1984).

Structural features of the rock masses are complex, because they were affected by two different deformation events (Corsi et al., 2001; Balbi, 2008) including a brittle-ductile event, which developed in five phases, and an extremely complex fragile event, consisting of at least six deformation phases, which led to the formation of various faults (direct, inverse, transfer and thrust) (Corsi, 2003; Balbi, 2008).

The morphostructural outlines of the study area are strongly influenced by brittle tectonic deformations. The coastal slopes are structurally controlled by normal faults at $\mathrm{N} 80^{\circ}$ and $\mathrm{N} 100^{\circ}$ strikings, whereas the hydrographic network is located along shear zones $\mathrm{N} 20^{\circ}-\mathrm{N} 160^{\circ}$ strikings.

From a hydrogeological point of view, the Mt. Antola limestones are globally characterised by a degree of permeability ranging from medium to scarce, depending on the local conditions. The variable permeability of the region is due to the ratio of lithoid to mudstone rock and to the spacing and orientation of joints.

Because of its depositional and tectonic characteristics, the Mt. Antola limestones cannot be analysed by an engineering geological approach designed for a common rock mass; thus, the region must be assessed as a structurally complex formation (Esu, 1977) or a heterogeneous rock mass 
(Marinos and Hoek, 2001). Although the lithoid rock component is calcareous, the Mt. Antola limestones can be regarded as a heterogeneous rock mass due to the presence of class B (sandstone with thin interlayers of siltstone) and C rock masses (sandstone and siltstone in similar amounts) and a Geological Strength Index (GSI) that ranges from 50 to 35 .

\section{Methods}

Because the basic rock mass structural features (ISRM, 1978) are visibly assessable from the sea, photoanalysis and terrestrial digital photogrammetry can be considered useful tools for remote characterisation and mapping of rock slope discontinuity sets, as it has been demonstrated by many studies (Franklin et al., 1988; Crosta, 1997; Lemy et al., 2003; Haneberg et al., 2006; Poetsch et al., 2007; Haneberg, 2008; Ferrero et al., 2009). In fact, high rocky coasts are peculiar, because the structural features of the rock mass are generally well-exposed but not easily measurable due to the accessibility of the sites. Access to rocky coasts can be prevented by the presence of cliffs (where direct discontinuity measurements may be impractical or hazardous) and/or limitations imposed by private properties. On the other hand, tightly controlled photographs of the sea cliff cannot be taken with a camera from a stable position, but only from a boat. In addition, to survey an extensive coastal sector, many photographs must be analysed.

The specific conditions of the study area and the continuously variable geometry of the rock exposures on the sea cliff affect the rigorous analysis of digital photographs with computer-aided techniques for 3-D characterisation of discontinuities (Haneberg, 2008; Lemy et al., 2003; Ferrero et al., 2009), requiring the orientation of photographs by means of visible targets located by specialised rock climbers.

Due to the abovementioned constraints, enhanced by the extension of the coastal sector, visual estimation of the geometrical features of discontinuities from stereoscopic observations of stereopairs was considered satisfactory, even if the estimation was recognised as affected by a limited subjectiveness of the operator's judgment.

The approximate estimation of the attitude of a planar geological surface by outcropping in an inaccessible area is a well-known field non-contact technique that is performed by field geologists orienting a rigid tablet as the spatial perception of the plane and measuring its attitude by means of a geologic compass. The capability of an observer to perceive depth and 3-D object shape from binocular disparity is a well-studied issue (Helmholtz, 1925; Ogle, 1950, 1958) and constitutes the theoretical basis for modern techniques of 3-D vision (Okoshi, 1976; Trucco and Verri, 1999), as well as a basic skill used in photogeological analyses (Allum, 1966; Lattmann, 1992; Miller, 1992). In the common practice, this indirect estimation can be more accurate than a single direct measurement carried out with a compass, espe- cially in the case of very rough and irregular planar surfaces that require the use of support discs with increasing diameters (Fecker and Rengers, 1971; Hoek, 1972; ISRM, 1981). Another case is that of a surface confused among others that can be better recognised from a certain distance than directly on the outcrop (e.g. bedding in highly fractured sedimentary rock masses).

The proposed method was based on the following criteria: (a) continuous stereoscopic photographic view of the coastal slopes; (b) geological and geomorphological analyses of stereopairs; (c) detailed meso and macrostructural analysis of the rock mass; and (d) analyses of the stability of rock slopes according to the Matheson's tests (Matheson, 1983).

Geological and structural data were graphically represented on a photographic view of the coastal slopes reconstructing an engineering geological map (Griffiths, 2002).

\subsection{Photographic surveys}

Digital photos of the sea cliffs were taken from a boat sailing parallel to the coastline along a pre-established route tracked by continuous GPS measurements, approximately $160 \mathrm{~m}$ from the coast. A 10 megapixel digital camera with a focal length of $70 \mathrm{~mm}$ was used to photograph the study region. Because the distance from the coastline was known, approximate dimensions of the photographed area in each frame were estimated to be $56 \mathrm{~m}$ (horizontal) $\times 42 \mathrm{~m}$ (vertical), if the projection of each frame was passed through a vertical plane passing through the coastline. The photos referred to a progressive distance along the coastline corresponding to the route of the boat, which sailed from Rapallo to Chiavari (about $5700 \mathrm{~m}$ ). To attain the stereoscopic analysis, the photos (231 shots) were taken to achieve a $60 \%$ overlap between frames. Each photograph was taken every $20 \mathrm{~m}$, and the ratio between the baseline and the distance from the sea cliff was approximately 0.125 ; thus, a good stereoscopic view was obtained. The photographs were taken every $15 \mathrm{~s}$ at a speed of approximately 3 knots and by the direct observation of the operator.

The photos were joined to obtain a continuous view of the coast. Because of the variable morphology of the slopes in each frame, which are approximately vertical above the coastline and more gently sloping in the higher regions of the rock mass, the images were mounted according to the mutual overlap of the coastline, up to the rocky steep cliffs. Hence, the obtained photographic view can be considered geometrically consistent and reliable for the steep slopes and vertical cliffs that stand above the coastline.

\subsection{Estimation of geostructural data by stereoscopic analysis}

Mesoscale structural features of the rock mass were analysed and reconstructed from the stereoscopic analysis of stereopairs. Because the orientation of the route was known and 



Fig. 3. Error tests between indirect estimations and direct measurements (191 samples derived from two test areas) of dip direction (a) and dip of planar discontinuities (b). Test areas are shown in Fig. 2.

the photos were taken perpendicularly to the boat length, discontinuities (bedding, joints and faults) were identified and spatially oriented (ISRM, 1978) through stereoscopic observations and geometric evaluations. A rigid tablet and a geologic compass were used, virtually considering the North as corresponding to the direction of photography. Subsequently, dip direction data were corrected considering the angle formed between the direction of the photography (normal to the route) and the North. Moreover, to constrain the estimation of the spatial orientation of the discontinuities, stereoscopic estimations were based relatively to the appearance of structural slopes, generally controlled by the bedding, whose attitude was estimated by the topographical map.

In order to test the reliability of the non-contact estimations provided by the analysis of stereopairs, two accessible sample areas near Zoagli (Fig. 2) were tested. A comparison between the attitude data provided by in situ measurements and the stereoscopic estimations was made considering, respectively 102 and 89 discontinuities belonging to different joint sets. The tests revealed that the errors of estimation were normal distributed, with a median value approximately equal to zero, variable in the $90 \%$ and $50 \%$ ranges of probability, respectively $\pm 20^{\circ}$ and $\pm 8^{\circ}$ both for dip direction and for dip (Fig. 3a and b). Such results were considered as validating the non-contact estimation, also taking into account that the standard density analysis of poles carried out on geostructural data tends to the annulment of the error in identifying the representative pole of each joint set (Fig. 4). Moreover, the median value of the errors $(\varepsilon)$ evaluated for intervals of $20^{\circ}$ of dip direction and $10^{\circ}$ of dip result, respectively limited in the range of $-20^{\circ}<\varepsilon<10^{\circ}$ and $-5^{\circ}<\varepsilon$ $5^{\circ}$ (Fig. 5a and b).

To improve the objectiveness in the interpretation of the structural features of the rock mass, observations were made by two different operators, and the results were integrated.
Each operator analysed the entire rock mass by applying the sampling window technique (Pahl, 1981; Priest, 1993); however, different detection methods were employed, as follows: (a) the identification and geometric characterisation of all visible discontinuities on the rocky slope; (b) the analysis and interpretation of the fundamental structural features of the rock mass. The second procedure allowed highlighting also those structural features that were statistically underrepresented in the systematic analysis of discontinuities (Terzaghi, 1965; Priest and Hudson, 1976; 1981; Priest, 1993). This procedure reduced the underestimation of structural features that possess an attitude similar to the orientation of the slope faces. These features are common in bedding planes that have an attitude that is parallel to that of the coastal cliff and are often underestimated if compared to discontinuity sets that are perpendicular to the coastline. Because the different methods provided similar results, a more objective model of the orientation of discontinuities was achieved. The results obtained by the two methods were graphically represented on the photographic view of the rocky slopes (Fig. 6).

\subsection{Shear strength of the rock joints}

The flysch rock mass in the study area is characterised by lithological heterogeneity due to the rhythmic alternation of hard calcareous rock strata (marly limestones, calcareous marls and arenaceous limestones) and weak mudstone interlayers (i.e., range $e$ of the Bouma sequence) and the strong effect of the bedding attitude on the rock slope stability. Due to the anisotropy and heterogeneity of the rock mass, it was necessary to assess the shear strength of the bedding interlayer. Nevertheless, in-situ and laboratory tests were not considered economically feasible at providing reliable information on the shear strength of the rock mass due to the scale of the study. 



Fig. 4. Density plots of poles for direct measurements (a and $\mathbf{c}$ ) and non-contact estimations (b and d) of two test areas with respectively 89 and 102 geostructural data. Test areas are shown in Fig. 2.

The determination of the shear strength of a mudstone interlayer is very complex, because mudstones commonly present a high degree of overconsolidation and are strongly anisotropic due to the presence of sedimentary structures and the isorientation of clay minerals. Therefore, geomechanical characterisation of these materials through laboratory tests is extremely problematic due to the difficulties associated with sample collection and the inadequacy of laboratory equipment for the management of the anisotropy of mudstones (Kwasniewski, 1993). Moreover, a fundamental aspect to be considered in the geomechanical characterisation of mudstone interlayers is the progressive physical alteration (weathering) caused by imbibitions and drying cycles. This process alters the structure of weak rocks and leads to a sharp decline in their mechanical strength. Over time, weathering can transform weak rocks into soils (Taylor and Cripps, 1987). Due to the difficulties in measuring the shear strength of mudstones and the observation that the dip of the structural slope is controlled exclusively by bedding, the critical value of the rock slope stability was set to $45^{\circ}$. This value was identified, because it exceeds the average dip of the bedding planes (approximately $40^{\circ}$ ), thus, giving a daylighting con- dition that is predisposing to the kinematic release. Sliding rock failures can occur along bedding discontinuities when the shear strength of mudstone interlayers reduces, by means of alteration, to an equivalent friction angle equal to the dip of bedding itself.

Due to the scale of the study, a unique value of the shear strength for calcareous rocks, even if represented by various lithotypes, was estimated applying the Barton and Choubey (1977) equation:

$\tau=\sigma_{\mathrm{n}} \cdot \operatorname{tg}\left[\varphi_{\mathrm{b}}+\mathrm{JRC} \cdot \log _{10}\left(\frac{\mathrm{JCS}}{\sigma_{\mathrm{n}}}\right)\right]$

where:

$\sigma_{n}=$ effective vertical stress;

$\varphi_{b}=$ basic friction angle $\left(^{\circ}\right)$;

$\mathrm{JRC}=$ joint roughness coefficient;

JCS $=$ joint compressive strength.

From what it follows that the total friction angle is

$\varphi=\varphi_{\mathrm{b}}+\mathrm{JRC} \cdot \log _{10}\left(\frac{\mathrm{JCS}}{\sigma_{\mathrm{n}}}\right)$

In situ tests were conducted to characterise the Joint Compressive Strength (JCS) and the Joint Roughness 

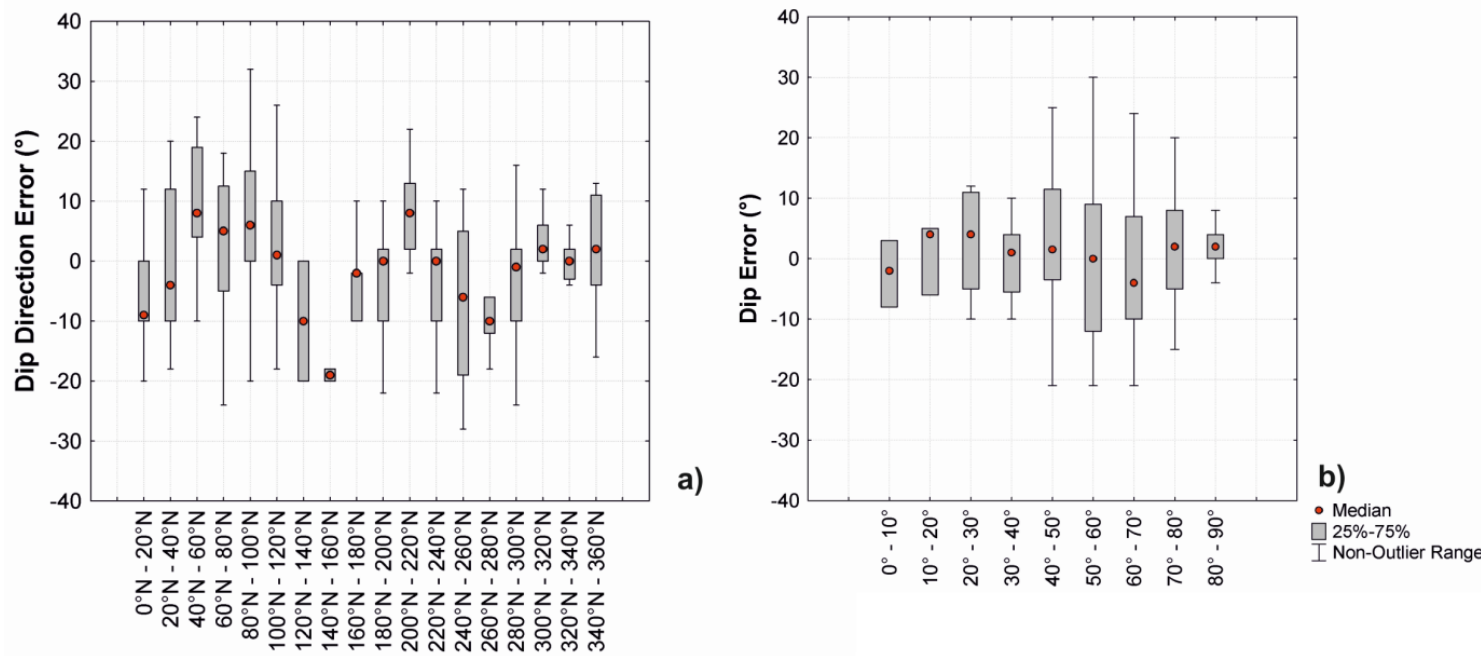

Fig. 5. Box plots of errors on dip direction (a) and dip (b) of 191 geostructural data identified in two accessible test areas (Fig. 2).

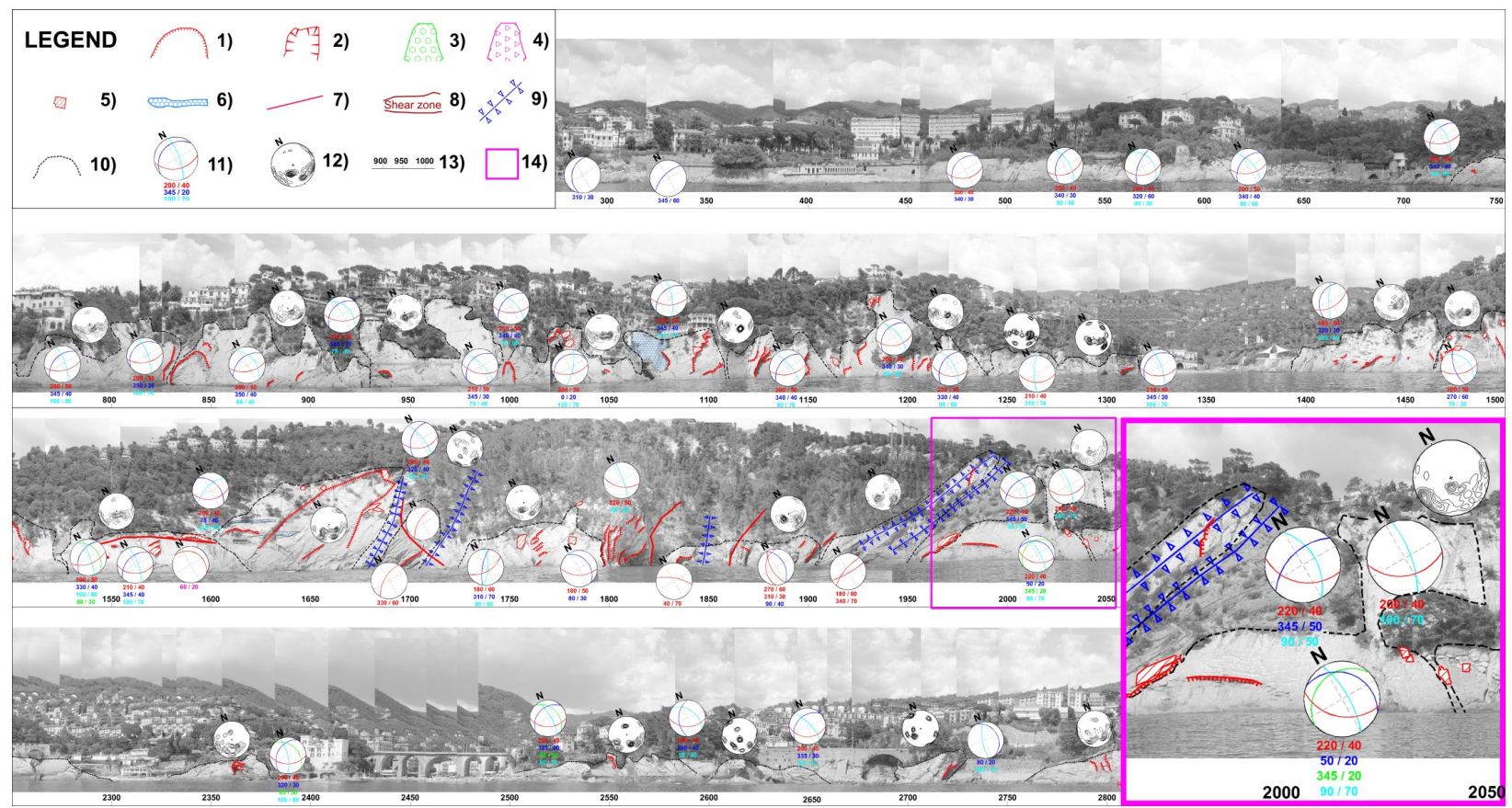

Fig. 6. Photographic view of the coastal stretch between Rapallo and Zoagli (Fig. 10a). Legend: (1) traces of detached rock blocks; (2) landslide crowns; (3) detrital deposits; (4) landslide accumulations; (5) unstable rock blocks; (6) remedial works for the mitigation of landslide hazard; (7) faults; (8) thrusts and shear zones; (9) folds axes; (10) survey areas for the systematic analysis of rock mass features; (11) discontinuity sets in the survey areas; (12) density plot of discontinuities in the survey area; (13) progressive distance from Rapallo (meters); (14) box of a zoomed view.

Coefficient (JRC) of the calcareous lithotypes of Mt. Antola limestones, where logistic conditions and the constraints of private properties allowed the operations to be executed (a total of 27 survey stations between Rapallo and Chiavari were investigated, Fig. 2). We respectively applied a Schmidt hammer and a profilometer.

\subsection{Rock block stability analysis}

Rock blocks may be subject to instability along a slope, depending on the geometrical relationships between the attitude of the discontinuities and the orientation of the slope. Considering the characteristics of the rock mass in the study area, 
three fundamental kinematic mechanisms of instability were considered, including planar sliding, wedge sliding and toppling (Hoek and Londe, 1974). The analysis of rock block stability due to planar sliding, wedge sliding and toppling was verified by using the graphical methods proposed by Matheson (1983).

The existence of favourable conditions for planar sliding was verified by overlapping Matheson's graph on the stereographic representation of the density plot of poles. The graph includes a circular sector of $\pm 20^{\circ}$ (total $40^{\circ}$ ) with a graduated series of arcs of concentric circles. To identify a sector of circular coronas, an inner arc of a circle representing the friction angle and an outer arc of a circle representing the slope dip angle were selected (Fig. 8a). The slope dip direction is marked by an arrow positioned in the opposite direction of the circular sector, because the latter refers to poles that oppose the dip direction. If the pole corresponding to the discontinuity set falls within the circular corona sector, its dip angle is greater than the friction angle and less than the slope dip, and the discontinuity can be considered to be affected by slide instability mechanism.

The existence of favourable conditions for wedge sliding was verified by superimposing a different graph on the stereographic representation of the great circles of the discontinuity set. The graph consists of an outer semicircle with a graduated series of concentric semicircumferences corresponding to the friction angle and a graduated series of Wulff's meridian arcs corresponding to the slope angle (Fig. 8b). The slope dip direction is marked by an arrow positioned in the same direction as the previous circular sector. If the intersection of circles corresponding to the discontinuity set fell inside a semicircle of a given friction angle and outside of a meridian arc of a given slope angle, that is, when the dip angle of the intersection between two discontinuities is greater than the friction angle and less than the slope angle, the discontinuity is considered to be affected by wedge sliding instability.

The existence of favourable conditions for direct toppling was verified by superimposing a third graph on the stereographic representation of the density plot and the great circles of the discontinuity sets (Fig. 8c). The graph consists of a semicircle corresponding to the poles of basal discontinuity (thus, the discontinuity must be localised in opposition to the slope dip direction) and a circular sector area corresponding to the intersections of discontinuity sets (thus, the discontinuities must be located in opposition to the slope dip direction and the intersections of the discontinuities must satisfy the first of the three requirements for toppling). In particular, the circular sector area is bounded by a range of $\alpha \pm 20^{\circ}$ (total $40^{\circ}$ ) with respect to the slope dip. Moreover, the sector contained a double circular graduation corresponding to concentric circle arcs. The first arc, which increased outwards, is related to the discontinuity poles, whereas the second arc, which increased inwards, corresponds to the intersections of the discontinuities.

\section{Results}

Stereoscopic analysis provided detailed information on the geological, structural and geomorphological features of the study area. In particular, macrostructural outlines such as fold axes, faults, shear zones and unstable rock blocks were identified. Moreover, detrital covers, landslide scars and accumulation zones, active and relict landslide crowns and rupture edges of rocky blocks were identified. Stereoscopic observations also provided information on the existing landslide mitigation works. All of these elements were mapped onto the photographs of the rocky slopes, along a vertical plane passing through the coastline (Fig. 6).

A total of 3075 discontinuities were identified, and each discontinuity was characterised by its spatial orientation and type (joints, faults and bedding). Subsequently, a density analysis of poles was performed locally for each sector, visible in one or more consecutive stereopairs. After, the data were aggregated into structurally homogeneous domains and globally analysed. To identify homogeneous structural conditions of the rock mass at the meso- and macroscale, the attitude of the bedding was used as a reference, because its variation was recognised as a clear expression of folding and faulting. Moreover, because mudstone interlayers due to turbiditic deposition characterise the Mt. Antola Flysch, these features were considered the most critical component for rock slope stability. To determine the stability of the slope, the dip direction and dip of the bedding along the coastline were analysed (Fig. 7).

On the basis of the bedding attitude, three different structural domains were recognised:

a. Domain 1 (NNE-SE): dip direction of the bedding planes $40^{\circ} \mathrm{N} \div 160^{\circ} \mathrm{N}$;

b. Domain 2 (SE-WSW): dip direction of the bedding planes $160^{\circ} \mathrm{N} \div 240^{\circ} \mathrm{N}$;

c. Domain 3 (WSW-NNW): dip direction of the bedding planes $240^{\circ} \mathrm{N} \div 340^{\circ} \mathrm{N}$.

Domain 2 is the most extensive one and shows a more regular orientation of the bedding planes, which dip downstream with a dip value of approximately $40^{\circ}$. This condition, combined with the orientation of the coastline, indicated the presence of structural slopes strongly controlled by the bedding attitude. Alternatively, for the other two domains, more localised deformations and meso-scale structures including folds, faults or thrusts were observed.

The geomechanical tests were carried out on lithotypes including marly limestone, calcareous marl and arenaceous limestones (Table 1) and together with other evaluations, allowed the application of the Barton and Choubey (1977) Eq. (2). Given the general superficiality of instability phenomena involving single rock blocks, the choice of a normal 


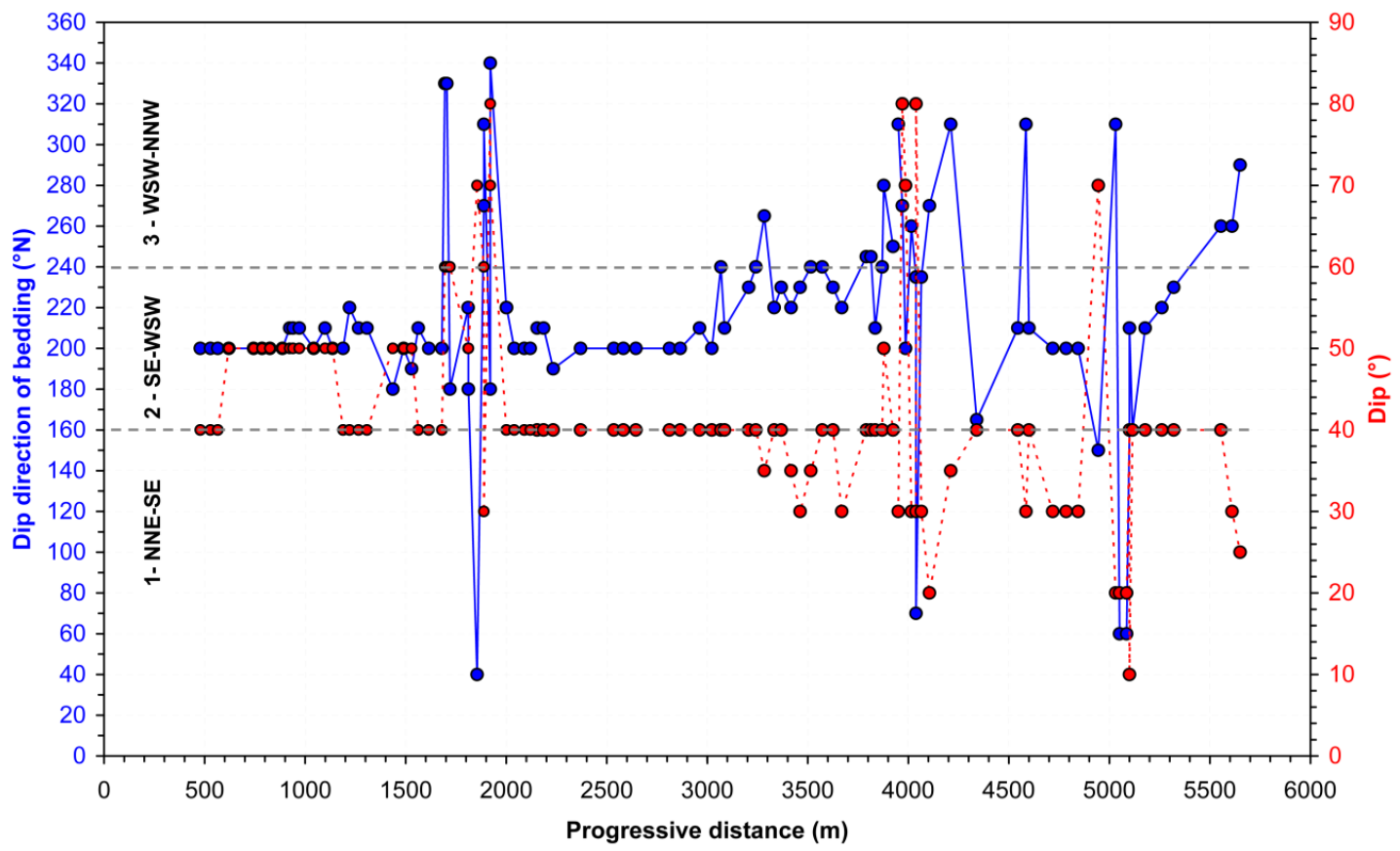

Fig. 7. Bedding attitude along the coastline from Rapallo to Chiavari. Three structural domains with different bedding attitude were recognised.

Table 1. Joint Compression Strength (JCS) and Joint Roughness Coefficient (JRC) values of representative lithotypes of the Mt. Antola limestone. Survey stations are shown in Fig. 2.

\begin{tabular}{lllll}
\hline Lithology & $\begin{array}{l}\text { No. } \\
\text { of tests }\end{array}$ & $\begin{array}{l}\text { JCS } \\
\text { (MPa) }\end{array}$ & $\begin{array}{l}\text { No. } \\
\text { of tests }\end{array}$ & JRC \\
\hline Marly limestone & 32 & $84 \pm 15$ & 28 & $10 \pm 3$ \\
Calcareous marl & 14 & $47 \pm 12$ & 13 & $10 \pm 2$ \\
Arenaceous limestone & 16 & $92 \pm 24$ & 13 & $11 \pm 3$ \\
\hline
\end{tabular}

stress equal to a depth of $3 \mathrm{~m}$ was considered a precautionary condition.

The following values were considered for the application of the Barton and Choubey (1977) equation: $\varphi_{b}=32^{\circ}$ (precautionary value for calcareous marls by Barton, 1973); $\mathrm{JRC}=10$ (value for calcareous marl); JCS $=47 \mathrm{MPa}$ (value for calcareous marl); $\sigma_{n}=80.1 \mathrm{kN} \mathrm{m}^{-2}$ (corresponding to normal stress, not exceeding a depth of $3 \mathrm{~m}$, with $\gamma=26.7 \mathrm{kN} \mathrm{m}^{-3}$ ). From these values a total friction angle of $60^{\circ}$ was estimated.

Rock block stability analyses were conducted by considering two different values of the total friction angle: $\varphi=45^{\circ}$ for mudstone interlayers and $\varphi=60^{\circ}$ for discontinuities affecting calcareous lithotypes (including the joint roughness effect).
To conduct kinematic analyses, Matheson's tests were performed (Fig. 8). Slope dip directions (slope aspect) between $100^{\circ} \mathrm{N}$ and $280^{\circ} \mathrm{N}$ at a constant interval of $5^{\circ}$ were used as a reference. For each slope dip direction, the critical value of the slope angle in the three structural domains was identified (Fig. 9). In particular, fundamental kinematic conditions were identified, and discontinuity sets that, individually or in combination, could lead to critical conditions for rock block stability were determined (Table 2 and Fig. 9).

\subsection{Rock failure susceptibility mapping}

The aforementioned results were used to develop a rock failure susceptibility model based on the implementation of the geometry of slopes and the attitude of discontinuity sets in a Geographic Information System (GIS). Raster type GIS was designed to manage and analyse topographic data, creating a detailed Digital Elevation Model (DEM). According to the contour lines derived from the regional technical map (1:5000), the resolution of the DEM was set to $5 \times 5 \mathrm{~m}$. The slope angle $(\alpha)$ and the slope aspect maps (resolution $=5 \times 5 \mathrm{~m}$ ) were automatically obtained. Through a mapping overlay procedure, the slope angle and aspect were used to identify areas where two critical conditions for the stability of rock blocks coexisted, according to results obtained from the Matheson's tests carried out for each structural domain (Table 2 and Fig. 9).

In coastal sectors where a sliding rock failure mechanism involving bedding planes and shear strength of mudrock 


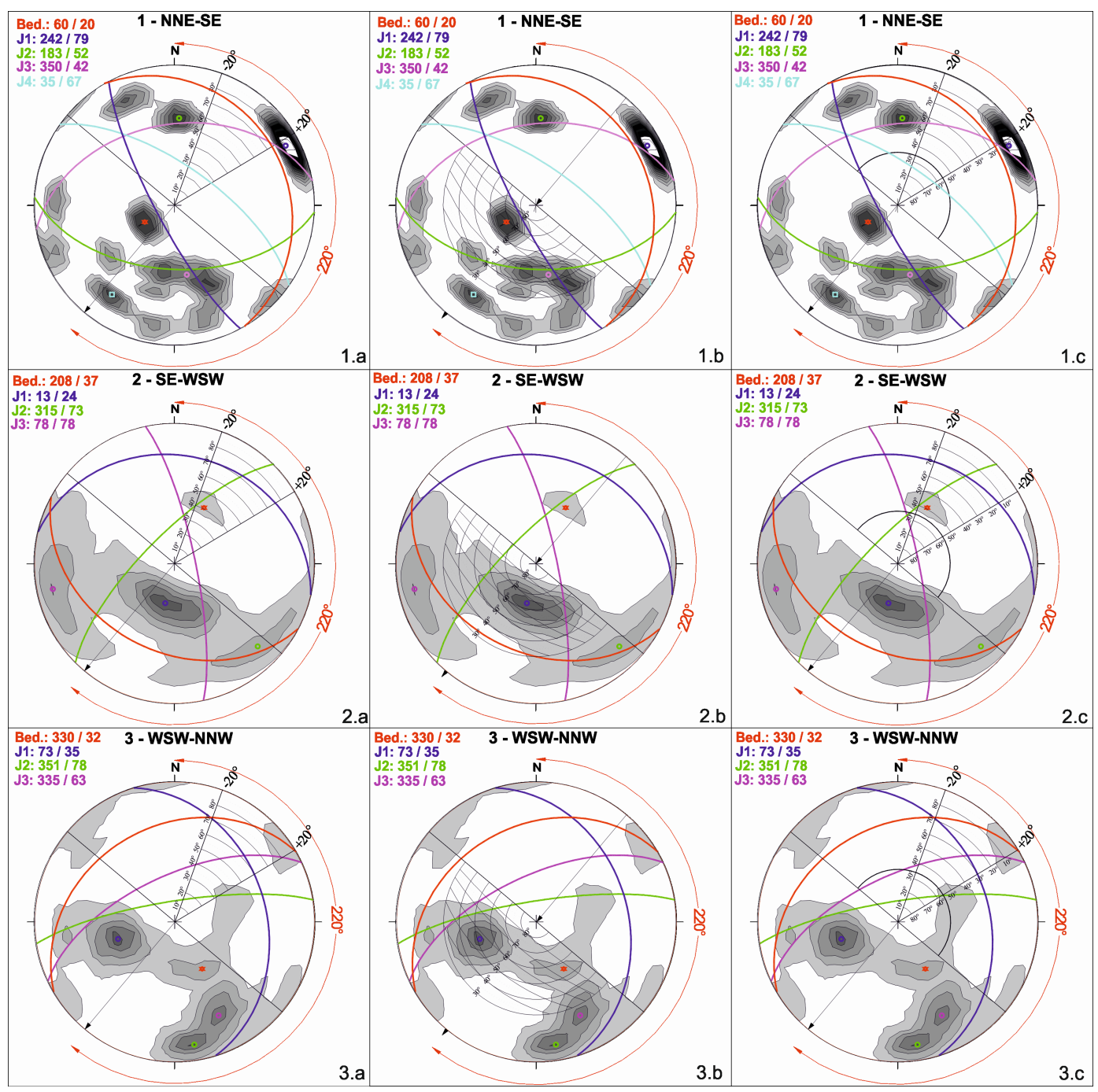

Fig. 8. Matheson's test, referenced to a slope dip direction of $220^{\circ}$ and applied to structural domains 1 to 3 (rows 1,2 and 3 ) and to mechanisms of instability for plane sliding (column a), wedge sliding (column b) and toppling (column c).
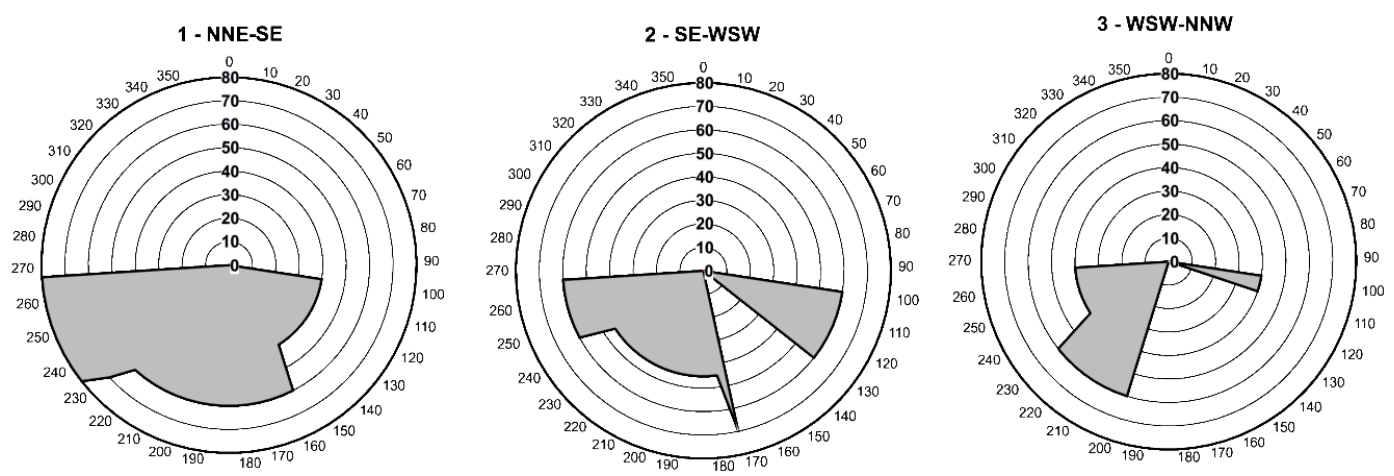

Fig. 9. Critical slope angles corresponding to the fundamental mechanisms of rock slope instability (plane sliding, wedge sliding and toppling) in the slope dip direction $100^{\circ} \mathrm{N} \div 270^{\circ} \mathrm{N}$ (Table 2) for the three structural domains 1,2 and 3 (Fig. 7). 
Table 2. Results of the stability analyses of the identified structural domains. Numbers in the column "Critical Conditions" indicate: (1) discontinuity daylighting; (2) basal discontinuity daylighting; (3) shear strength of rock joints; and (4) shear strength of marly/mudstone interlayers.

\begin{tabular}{|c|c|c|c|c|c|c|}
\hline $\begin{array}{l}\text { Structural } \\
\text { domain }\end{array}$ & $\begin{array}{l}\text { Failure } \\
\text { type }\end{array}$ & $\begin{array}{l}\text { Critical } \\
\text { joint set }\end{array}$ & $\begin{array}{l}\text { Discontinuities } \\
\text { orientation }\end{array}$ & $\begin{array}{l}\text { Critical } \\
\text { azimuth range }\end{array}$ & $\begin{array}{l}\text { Critical } \\
\text { slope angle }\end{array}$ & $\begin{array}{l}\text { Critical } \\
\text { Conditions }\end{array}$ \\
\hline \multirow{5}{*}{1 - (NNE-SE) } & \multirow{3}{*}{ Plane sliding } & $\mathrm{J} 1$ & $242 / 79^{\circ}$ & $100^{\circ} \mathrm{N} \div 115^{\circ} \mathrm{N}$ & $80^{\circ}$ & 1 \\
\hline & & $\mathrm{J} 2$ & $183 / 52^{\circ}$ & $130^{\circ} \mathrm{N} \div 200^{\circ} \mathrm{N}$ & $60^{\circ}$ & 3 \\
\hline & & $\mathrm{J} 1$ & $242 / 79^{\circ}$ & $220^{\circ} \mathrm{N} \div 270^{\circ} \mathrm{N}$ & $80^{\circ}$ & 1 \\
\hline & Wedge sliding & $\mathrm{J} 1 \cap \mathrm{J} 2$ & $242 / 79^{\circ} \cap 183 / 52^{\circ}$ & $100^{\circ} \mathrm{N} \div 245^{\circ} \mathrm{N}$ & $60^{\circ} \div 80^{\circ}$ & $3-1$ \\
\hline & Direct toppling & $\begin{array}{l}\mathrm{J} 2 \cap \mathrm{J} 3 \\
\text { (Bedding) }\end{array}$ & $\begin{array}{l}183 / 52^{\circ} \cap 350 / 42^{\circ} \\
\left(60 / 20^{\circ}\right)\end{array}$ & $100^{\circ} \mathrm{N} \div 150^{\circ} \mathrm{N}$ & $40^{\circ}$ & 2 \\
\hline \multirow{3}{*}{$2-(\mathrm{SE}-\mathrm{WSW})$} & \multirow{2}{*}{ Plane sliding } & $\mathrm{J} 3$ & $78 / 78^{\circ}$ & $100^{\circ} \mathrm{N} \div 130^{\circ} \mathrm{N}$ & $60^{\circ}$ & 3 \\
\hline & & Bedding & $208 / 37^{\circ}$ & $175^{\circ} \mathrm{N} \div 240^{\circ} \mathrm{N}$ & $45^{\circ}$ & 4 \\
\hline & Wedge sliding & $\mathrm{St} \cap \mathrm{J} 2$ & $208 / 37^{\circ} \cap 315 / 73^{\circ}$ & $170^{\circ} \mathrm{N} \div 280^{\circ} \mathrm{N}$ & $45^{\circ}$ & 4 \\
\hline \multirow{5}{*}{$3-($ WSW-NNW) } & \multirow{2}{*}{ Plane sliding } & $\mathrm{J} 1$ & $73 / 35^{\circ}$ & $100^{\circ} \mathrm{N} \div 110^{\circ} \mathrm{N}$ & $60^{\circ}$ & 3 \\
\hline & & Bedding & $330 / 32^{\circ}$ & $250^{\circ} \mathrm{N} \div 280^{\circ} \mathrm{N}$ & $45^{\circ}$ & 4 \\
\hline & Wedge sliding & $\mathrm{J} 2 \cap \mathrm{J} 3$ & $351 / 78^{\circ} \cap 335 / 63^{\circ}$ & $200^{\circ} \mathrm{N} \div 280^{\circ} \mathrm{N}$ & $60^{\circ}$ & 3 \\
\hline & \multirow[t]{2}{*}{ Direct toppling } & $\begin{array}{l}\mathrm{J} 2 \cap \mathrm{J} 3 \\
(\mathrm{~J} 1)\end{array}$ & $\begin{array}{l}352 / 78^{\circ} \cap 335 / 63^{\circ} \\
\left(73 / 35^{\circ}\right)\end{array}$ & $100^{\circ} \mathrm{N} \div 110^{\circ} \mathrm{N}$ & $40^{\circ}$ & 2 \\
\hline & & $\begin{array}{l}\mathrm{J} 1 \cap \mathrm{J} 2 \\
\text { (Bedding) }\end{array}$ & $\begin{array}{l}73 / 35^{\circ} \cap 352 / 78^{\circ} \\
\left(330 / 32^{\circ}\right)\end{array}$ & $240^{\circ} \mathrm{N} \div 270^{\circ} \mathrm{N}$ & $40^{\circ}$ & 2 \\
\hline
\end{tabular}

interlayers was recognised (case 4 in Table 2), two classes of susceptibility to rock failure were established (Fig. 10):

a. medium susceptibility, where $45^{\circ}<\alpha<60^{\circ}$;

b. high susceptibility, where $\alpha>60^{\circ}$.

The first class (a) was identified considering both the daylighting of bedding on the slope (dip < slope dip) and the possibility to rock failure in relationship to the decrease in shear strength of the mudrock interlayers due to weathering. The second class (b) was considered more hazardous than the former due to the potential simultaneous mobilisation of plane sliding, which depends on the shear strength of mudstone interlayers, and wedge sliding, which depends on the shear strength of calcareous rocks joints $\left(\phi=60^{\circ}\right)$.

For those coastal sectors where rock failure mechanisms involve only the shear strength of calcareous rock joints $\left(\phi=60^{\circ}\right)$, a single category was considered:

c. high susceptibility, where $\alpha>60^{\circ}$.

Subordinate areas, where detrital covers outcrop, were not included in the GIS analysis. The results provided by the distributed stability model were more strongly affected by the DEM's resolution than the quantity and quality of geological and structural data.

\section{Conclusions}

The data and methods discussed in this paper can be considered both representatives of a particular case study, typical of an unstable coastal rocky cliff, and of a specific methodological approach.

This paper outlines a cost-effective and reliable methodology for the assessment of rock failure susceptibility in inaccessible areas such as high, steep, rocky coasts. The methodology is based on the application of a non-contact method for the analysis of rock mass structural features. The method consisted of the estimation of the attitude of discontinuities by means of their geometric spatial perception evaluated by an operator through stereoscopic analysis of photographs. Such an indirect method, already used by field geologists for evaluating the attitude of a planar geological surface outcropping in inaccessible areas, was proved to have limited and acceptable errors with multiple estimations and a basic statistical treatment of data.

In order to limit errors, diverse analytical approaches were carried out by two different operators. Hence, the systematic estimation of the discontinuities and the determination of the principal structural features provided balanced results that were less affected by unfavourable attitudes of discontinuities.

Results of non-contact geostructural surveys were used to analyse the fundamental mechanisms of instability of rock slopes formed by a structurally complex flysch rock mass. 


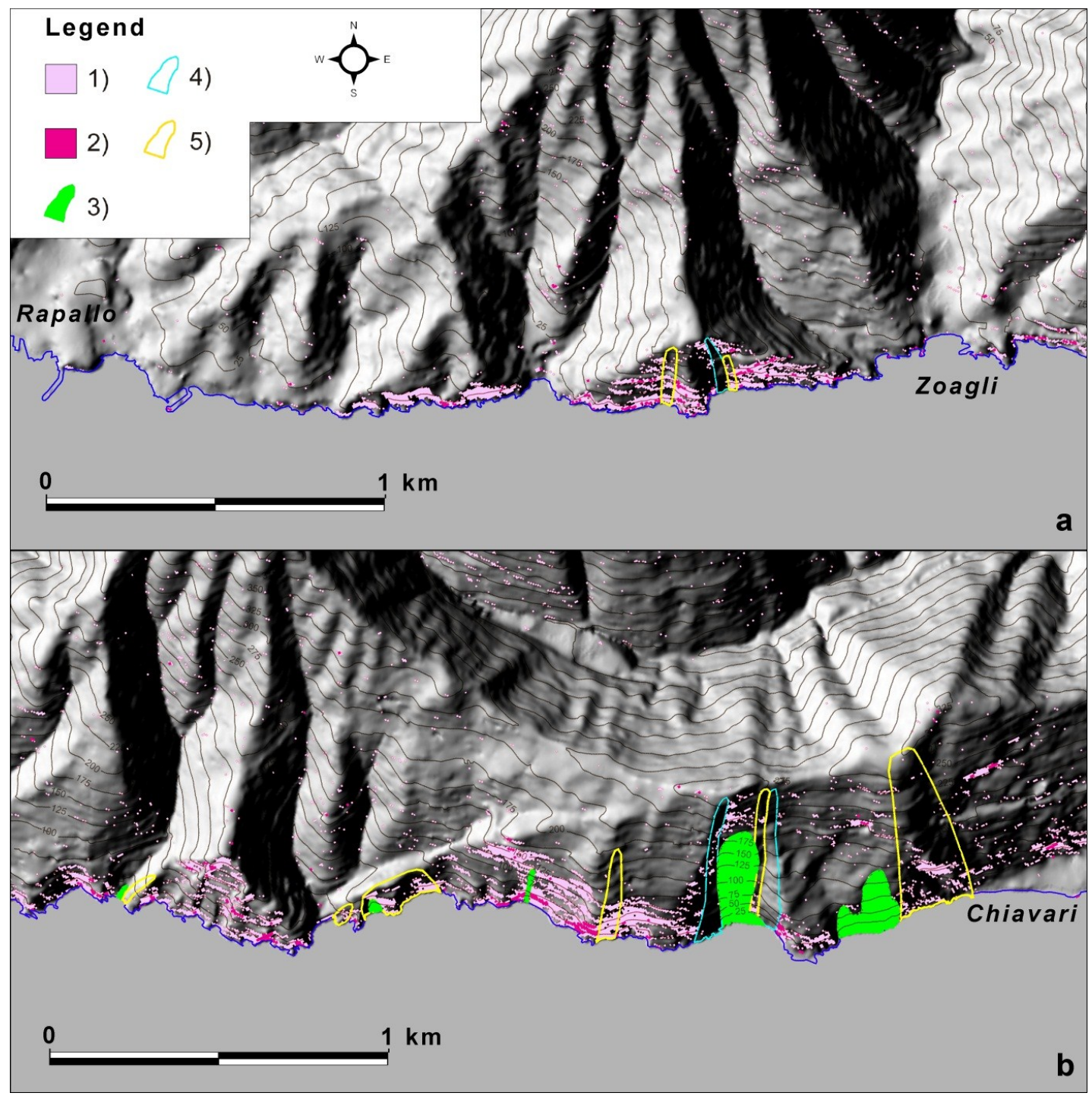

Fig. 10. Rock failure susceptibility map. Legend: (1) medium susceptibility for rock slope failure; (2) high susceptibility for rock slope failure; (3) poorly stable detrital cover; (4) limits of Domain 1; (5) limits of Domain 3 (other areas correspond to Domain 2).

The analyses allowed identifying the critical conditions for the stability of rock slopes through the application of Matheson's graphical tests. Subsequently, a distributed rock failure susceptibility model, based on the implementation of a GIS in the slope aspect, slope angle and in the geostructural data, was developed by obtaining a susceptibility map. About $40 \%$ of the coastal cliff, with a slope angle ranging from $40^{\circ}$ to $60^{\circ}$, was characterized with a medium susceptibility class for plane sliding mechanism, due to the daylighting condition of the bedding and the expected decrease of shear strength for mudrock interlayers. A limited part of the area was classified with high susceptibility, due to cliffs with slope angle greater than $60^{\circ}$ where both plane sliding along mudrock interlayers, and wedge sliding along calcareous rocks joints, may occur.
Results proved that the proposed method is useful for the assessment of the rock failure susceptibility in extended rocky coastal cliffs and large steep rocky slopes, whose limited accessibility prevents the structural analysis of the rock mass through direct surveys such as scanline or window sampling techniques. Moreover, in these difficult conditions and for large exposure of potentially instable rock masses, the adoption of quantitative photogrammetric techniques relying on the rigorous analysis of photographs through photoanalysis and terrestrial photogrammetry would be very expensive. If compared to other techniques, the proposed method provides more data on the structural features of the rock mass at a low cost and in a reliable manner.

Further improvements in the implementation of rock slope stability criteria in the distributed model could be obtained 
by employing higher resolution DEMs derived from more detailed aerial photogrammetric surveys or LIDAR technology.

In future studies, rockfall hazards of the study area could be assessed. In particular, the probability of wave heights and energies with a certain magnitude could be introduced into the model to improve the determination of rock failure susceptibility and to provide a temporal and spatial probability of rock fall occurrence. However, to include wave characteristics into rock failure susceptibility determination, an empirical or numerical model of rock block stability and wave energy must be developed.

Acknowledgements. The authors would like to thank two anonymous reviewers for useful and valuable comments. This work has been funded by the Liguria Regional Government.

Edited by: T. Glade

Reviewed by: two anonymous referees

\section{References}

Allum, J. A. E.: Photogeology and regional mapping. Pergamon, 107 pp., 1966.

Andriani, G. F. and Walsh, N.: Rocky coast geomorphology and erosional processes: A case study along the Murgia coastline South of Bari, Apulia - SE Italy. Geomorphology, 87, 224-238, 2007.

Angeli, M. G., Barbarella, M., and Pontoni, F.: Instability of a sea cliff: Sirolo landslide, Italy. Proceedings $6^{\text {th }}$ International Symposium Landslides, Christchurch (New Zealand), 10-14 February, 1093-1100, 1992.

Balbi, P.: Studio dei rapporti tra l'Unità del Monte Antola e l'Unità del Monte Gottero nell'ambito del quadro evolutivo paleo-eocenico del sistema Alpi-Appennini nella Liguria orientale. Dip.Te.Ris., University of Genoa, Ph. D. Thesis, 2008 (in Italian).

Barton, N. R.: Review of the shear strength criterion for rock joints, Eng. Geol., 7, 287-332, 1973.

Barton, N. R. and Choubey, V.: The shear strength of rock joints in theory and practice, Rock Mechanics, 10, 1-54, 1977.

Brabb, E. E., Pampeyan, E. H., and Bonilla, M. G.: Landslide susceptibility in San Mateo County, California, U.S. Geological Survey, Misc. Field Studies. Map MF-360, Scale 1:62500, 1972.

Budetta, P., Santo, A., and Vivenzio, F.: Landslide hazard mapping along the coastline of the Cilento region (Italy) by means of a GIS-based parameter rating approach, Geomorphology, 94, 340352, 2008.

Canuti, P., Casagli, N., and Tarchiani, U.: Rock fall hazard in coastal cliffs. Proceedings of 8th IAEG Congress, Vancouver, Balkema Ed, Rotterdam, The Netherlands, 1585-1592, 1998.

Cevasco, A.: I fenomeni d'instabilità nell'evoluzione della costa alta delle Cinque Terre (Liguria orientale). Studi costieri, 13, 93109, 2007 (in Italian).

Cevasco, A., Ferrari, M., Fierro, G., and Nosengo, S.: Fenomeni d'instabilità della costa alta e rocciosa fra Riva Trigoso e Framura (Liguria Orientale): risultati preliminari, Studi costieri, 3, 71-83, 2000 (in Italian).
Clark, J. R.: Integrated management of coastal zones. FAO Fisheries Technical Paper, 327, Rome, FAO, 167 pp., 1992.

Corsi, B.: Eventi tettonico-sedimentari del settore tra Chiavari e Genova Nervi nel quadro dell'evoluzione geodinamica del sistema Ligure Balearico e Tirrenico. Dip.Te.Ris., University of Genoa, Ph. D. Thesis, 2003 (in Italian).

Corsi, B., Elter, F. M., and Giammarino, S.: Structural fabric of the Antola Unit (Riviera di Levante, Italy) and implications for its alpine versus Apennine origin, Ofioliti, 26, 1-8, 2001.

Cortesogno, L. and Haccard, D.: Note illustrative alla carta della zona Sestri-Voltaggio. Mem. Soc. Geol. It., 28, 115-150, 1984 (in Italian).

Cotecchia, V.: The vulnerable town and the geological evolution of the middle Adriatic coastal environment, in: Proceeding of the IAEG International Symposium "Engineering Geology and Environment”, Athens, Greece, 1997.

Cotecchia, V.: The Second Hans Cloos Lecture. Experience drawn from the great Ancona landslide of 1982, Bull. Eng. Geol. Environ., 65, 1-41, 2006.

Crosta, G.: Evaluating Rock Mass Geometry From Photographic Images, Rock Mech. Rock Eng., 30, 35-58, 1997.

De Stefanis, A., Marini, M., and Terranova, R.: Indagini geologiche e geomorfologiche in Liguria con particolare riguardo alle condizioni di franosità. Memoria riepilogativa della U.O. 37. C.N.R., P.F. Conservazione del Suolo, Sottoprogetto Fenomeni Franosi. "Geologia Applicata e Idrogeologia", XVIII, 3, 1-15, 1985 (in Italian).

Dobrovolny, E.: Landslide susceptibility in and near Anchorage as interpreted from topographic and geologic maps, in: National Research Council: The great Alaska earthquake of 1964 - Geology, Parts A-6, National Academy of Sciences, 735-745, 1971.

Elter, F. M., Giammarino, S., Balbi, P., Corsi, B., Muzio, G., and Viarengo, L.: Carta Geologica Regionale (CGR) sc. 1:25.000 tav. 231.1, 231.4 Chiavari Recco. Regione Liguria, 2005 (in Italian).

Esu, F.: Behavior of slopes in structurally complex formations, Proc. Intl. Symp. Geot. Struct. Complex Form., Capri, 2, 292304, 1977.

Fecker, E. and Rengers, N.: Measurement of large scale roughness of rock planes by means of profilograph and geological compass, Rock fracture, Proc. of Int. Symp. Rock Mech., Nancy, Paper I$18,1971$.

Federici, P. R., Baldacci, F., Petresi, A., and Serani, A.: Atlante dei Centri Abitati Instabili della Liguria. I. Provincia della Spezia. C.N.R. G.N.D.C.I., Regione Liguria, Università degli Studi di Pisa, 102 pp., 2001 (in Italian).

Fell, R., Corominas, J., Bonnard, C., Cascini, L., Leroi, E., and Savage, W. Z.: Guidelines for landslide susceptibility, hazard and risk zoning for land-use planning. Engineering Geology, 102, 8598.99-111, 2008.

Ferrero, A. M., Forlani, G., Rondella, R., and Voyat, H. I.: Advanced Geostructural Survey Methods Applied to Rock Mass Characterization, Rock Mech. Rock Eng., 42, 631-665, 2009.

Ferrero, A. M., Migliazza, M., Roncella, R., and Segalini, A.: Rock cliffs hazard analysis based on remote geostructural surveys: The Campione del Garda case study (Lake Garda, Northern Italy), Geomorphology, 125, 457-471, 2011.

Fiorillo, F.: Geological features and landslide mechanisms of an unstable coastal slope (Petacciato, Italy), Eng. Geol., 67, 255- 
267, 2003.

Franklin, J. A., Maerz, N. H., and Bennett, C. P.: Rock mass characterization using photoanalysis, Int. J. Mining Geol. Eng., 6, 97-112, 1988.

Griffiths, J. S.: Mapping in Engineering Geology, The Geological Society of London, 287 pp., 2002.

Günther, A. and Thiel, C.: Combined rock slope stability and shallow landslide susceptibility assessment of the Jasmund cliff area (Rügen Island, Germany), Nat. Hazards Earth Syst. Sci., 9, 687698, doi:10.5194/nhess-9-687-2009, 2009.

Haneberg, W. C.: Using close range terrestrial digital photogrammetry for 3-D rock slope modeling and discontinuity mapping in the United States, Bull. Eng. Geol. Environ., 67, 457-469, 2008.

Haneberg, W. C., Norrish, N. I., and Findley, D. P.: Digital outcrop characterization for 3-D structural mapping and rock slope design along Interstate 90 near Snoqualmie pass, Washington, in: Proceedings, 57th annual highway geology symposium, Breckenridge, Colorado, 27-29 September 2006, 146-160, 2006.

Helmholtz, H. von: Treatise on physiological optics (Vol. 3; J. P. C. Southall, Ed. \& Trans.), Rochester, NY: Optical Society of America, (Original work published 1867), 1925.

Hoek, E.: Rock slope engineering, Rock slope stability in open cast mining, Part 1 - Collection and interpretation of data required for slope analysis. Imperial College, Rock Mechanics Progress Report, No. 8, July, 1972, 131 pp., 1972.

Hoek, E. and Londe, P.: The design of Rock Slopes and Foundations. General report of Third Congress of the International Society for Rock Mechanics, Denver, 1974.

Hutchinson, J. N. and Bromhead, E. N.: Isle of Wight Landslides, edited by: McInnes, R. G. and Jakeways, J., in: Instability Planning and Management, Proceedings of the International Conference, Ventnor, Isle of Wight, UK, 20-23 May 2002, Thomas Telford, 2002.

Iadanza, C., Trigila, A., Vittori, E., and Serva, L.: Landslides in coastal areas of Italy. Geological Society, London, Special Publications; 2009; v. 322, 121-141, doi:10.1144/SP322.5, 2009.

ISRM: Suggested methods for the quantitative description of discontinuities. International Society of Rock Mechanics, Commission on Standardization of Laboratory and Field Tests, Int. J. Rock. Mech. Min., 15, 319-368, 1978.

ISRM: Rock characterization, testing and monitoring, in: ISRM Suggested Methods, edited by: Brown, E. T., Pergamon Press, 211 pp., 1981.

Kwasniewski, M. A.: Mechanical behaviour of anisotropic rocks, in: "Comprehensive Rock Engineering", edited by: Hudson, J. A., 1, Pergamon Press, 285-312, 1993.

Jongens, R., Gibb, J., and Alloway, B. V.: A new hazard zonation methodology applied to residentially developed sea-cliffs with very low erosion rates, East Coast Bays, Auckland, New Zealand, Nat. Hazards, 40, 223-244, 2007.

Lattmann, L. H.: Technique of mapping geologic fracture traces and lineaments on aerial photographs, in: Photogeology and Photogeomorphology, edited by: Foster, N. H., and Beaumont, E. A., Treatise of Petroleoum Geology Reprint Series, No. 19., American Association of Petroleum Geologists, 1992.

Lemy, F. and Hadjigeorgiou, J.: Discontinuity trace map construction using photographs of rock exposures, Int. J. Rock Mech. Mining Sci., 40, 903-917, 2003.
Marinos, P. and Hoek, E.: Estimating the geotechnical properties of rock masses such as flysch, Bull. Eng. Geol. Environ., 60, 85-92, 2001.

Marroni, M., Monechi, S., Perilli, N., Principi, G., and Treves, B.: Late Cretaceous flysch deposits of the Northern Apennines: age of inception of orogenesis-controlled sedimentation, Cretaceous Res., 13, 487-504, 1992.

Matheson, G. D.: Rock stability assessment in preliminary site investigations: graphical methods. Laboratory report 1039 of Transport and Road Research Laboratory, Berkshire, UK, 30 pp., 1983.

Miller, V. C.: Rapid dip estimation in photo-geological reconnaissance, in: Photogeology and Photogeomorphology, edited by: Foster, N. H. and Beaumont, E. A., Treatise of Petroleoum Geology Reprint Series, No. 19., American Association of Petroleum Geologists, 1992.

Ogle, K. N.: Researches in binocular vision, Philadelphia: W. B. Saunders, 1950.

Ogle, K. N.: Present status of our knowledge of stereoscopic vision, Archives of Ophthalmology, 60, 755-774, 1958.

Okoshi, T.: Three-Dimensional Imaging Techniques, Academic Press, New York, 1976.

Pahl, P. J.: Estimating the mean length of discontinuity traces, Int. J. Rock Mech. Mining Sci. Geomech. Abstr., 18, 221-228, 1981.

Poetsch, M., Schubert, W., and Gaich, A.: The application of metric 3D images for the mechanical analysis of keyblocks. In: Eberhardt E, Stead D, Morrison T (eds.) Rock mechanics: meeting society's challenges and demands: proceedings, 1st Canada-US rock mechanics symposium, Vancouver, Canada, 77-84, 2007.

Priest, S. D.: Discontinuity analysis for rock engineering. Chapman \& Hall, 473 pp., 1993.

Priest, S. D. and Hudson, J.: Discontinuity spacings in rock, Int. J. Rock. Mech. Min. Abstr., 13, 135-148, 1976.

Priest, S. D. and Hudson, J.: Estimation of discontinuity spacing and trace length using scanline survey, Int. J. Rock. Mech. Min. Abstr., 18, 183-197, 1981.

Radbruch, D. H.: Map showing areas of relative amounts of landslides in California. U.S. Geological Survey Open-File Report 70-270, 36 pp., map scale 1:500 000, 1970.

Schulz, W. H.: Landslide susceptibility revealed by LIDAR imagery and historical records, Seattle, Washington, Eng. Geol., 89, 6787, 2007.

Taylor, R. K. and Cripps, J. C.: Weathering Effects: Slopes in Mudrocks and Over-consolidated Clays. In: Slope Stability, edited by: Anderson, M. G. and Richards, K. S., John Wiley, 405-445, 1987.

Terranova, R.: Aspetti geomorfologici e geologico-ambientali delle Cinque Terre: rapporti con le opere umane (Liguria Orientale). Studi e Ricerche di Geografia, VII, 1, 39-90, 1984 (in Italian).

Terzaghi, R. D.: Sources of errors in joint surveys, Geotechnique, 15, 287-304, 1965.

Trucco, E. and Verri. A.: Introductory technique for 3-D computer vision, Prentice Hall, 343 pp., 1999.

Venturelli, G. and Frey, M.; Anchizone metamorphism sedimentary sequences of the Northern Apennines (preliminary results), Rend. Soc. It. Miner. Petrol., 33, 109-123, 1977. 